\title{
THE EFFECT OF GREEN PRODUCT AND GREEN PROMOTION ON INCREASED CONSUMER LOYALTY AT STARBUCKS COFFEE
}

\author{
Erina Subiantoro', Lexi Pranata Budidharmanto ${ }^{2}$ \\ Universitas Ciputra, Surabaya. Indonesia \\ 1esubiantoro@student.ciputra.ac.id \\ 21limbing@ciputra.ac.id
}

\begin{abstract}
The increasing of public awareness of the environment has made companies implement green product and green promotion strategies to increase consumer loyalty. Therefore, the purpose of this study is to determine the influence between green product and green promotion on consumer loyalty at Starbucks Coffee. This study used a sample of 203 respondents which were processed by multiple linear regression. The results showed that the green product and green promotion partially had a positive and significant effect on consumer loyalty. Green products have the biggest influence on consumer loyalty. This shows that green products have an important role in increasing consumer loyalty at Starbucks Coffee. Also the green promotion can increase the consumer loyalty too.
\end{abstract}

Keywords: green product, green promotion, consumer loyalty

\section{INTRODUCTION}

The Ministry of Industry stated that at the end of 2019 the growth of the food and beverage industry had increased by eight percent (Zuraya, 2019). As for the beverage business itself, the development could be higher. Starbucks as one of the well-known global coffee shop businesses, is also one of the companies that implements loyalty programs to maintain and increase consumer loyalty (Sari and Nurhayati, 2019). According to Kotler and Keller (2016: 153), consumer loyalty is defined as a strong role for consumers to buy a product or services they like which makes them repurchase the product with the same brand. Beside buying and enjoying the coffee, Starbucks consumers prefer to buy this product because the products sold are promoted to have ingredients that are safe and also environmentally friendly. According to Sari and Setiawan (2017), safe and attractive products make consumers more loyal and selective in choosing a product. 
Currently, public awareness regarding environment is starting to increase, given the many environment threats and disasters (Romdhoni et al. 2020). Public awareness has led business people to start adjusting their business and responding to environmental damage that has occurred. Many companies are now creating business concepts and products that are more environmentally friendly. Environmental friendly products that have no impact on environmental damage are known as Green Products. According to Suhaily and Darmoyo (2019), green products are categorized as goods that are made and produced with recycled packaging. Examples of environmentally friendly products, namely reusable packaging are products that are easily biodegradable and free from chemicals. Starbucks is one of the company that cares about the environment that has implemented environmentally friendly products. Starbucks has innovated to use products that can be recycled and also minimize the use of plastic.

A company's marketing strategy for selling products can't be separated from the promotion. Meanwhile, the promotion carried out by the company to change the public's view of environmentally friendly products is called green promotion (Kusuma et al. 2017). Starbucks has also implemented green promotion in its marketing strategy in a variety of ways, one of the most popular is the tumbler day which is held every month. They offer drinks at half price by bringing your own tumbler. The promotion is expected to educate consumers to reduce plastic use and raising awareness about the environment.

The previous research by Jabeen and Kavitha (2020) stated that green marketing strategies which include green products, green places, green promotions, green people and green packages have an effect on consumer loyalty. This research has some similarities, but the results may show differences because the object under study is also different. A few researchers have focused more on green marketing, while this research focuses on green products and green promotion on consumer loyalty. The researchers by Suhaily and Darmoyo (2019) stated that green products and green promotion have no significant effect on consumer loyalty.

\section{Green Product}

Rath in Hanifah et al. (2019) reveal green products are products that produced with environmentally friendly technology and are not harmful to the environment. Meanwhile, according to Suhaily and Darmoyo (2019), green products are categorized as goods that are made and produced with recycled packaging. Examples of environmentally friendly products, namely reusable packaging are products that are easily biodegradable and free from chemicals. These environmentally friendly products are included in the green marketing strategy to change consumer attitudes towards a product (Jabeen and Kavitha, 2020).

From the information above, it can be concluded that green products are products that do not cause harm to humans and the environment, products that do not use excessive resources and also do not involve animals, and do not produce waste that is difficult to decompose (Febriani, 2019). Customers who care about the 
environment usually prefer environmentally friendly products, because they pay more attention to health and also the environment (Suki, 2015). Sari and Setiawan (2017) reveals that safe and attractive products make consumers more loyal and selective in choosing a product. Iswanto (2019) revealed that green product can make a positive image of a company and it can also increase consumer loyalty. Therefore, this study aims to show the influences of green product on consumer loyalty at Starbucks Coffee.

\section{Green Promotion}

Green promotion is a promotion carried out by companies to change people's views regarding environmentally friendly products (Kusuma et al. 2017). According to Palaguna and Ekawati (2016), green promotion is included in advertisements that are used to carry out marketing strategies regarding environmental issues so that they can be distinguished from the promotion of other products by customers. Green promotion is also a campaign made by a company by carrying out programs and activities to love the environment, the campaign can improve the image of a company (Agustin et al. 2015). The success of selling environmentally friendly products is supported by the existence of green promotions that is carried out by a company (Febriani, 2019). Green promotion is also part of the green marketing strategy in promotional activities to change consumer attitudes towards the environment and increase consumer loyalty (Jabeen and Kavitha, 2020). So, this study aims to show the influences a green promotion on customer loyalty at Starbucks Coffee.

\section{Consumer Loyalty}

Consumer loyalty is defined as a strong role for consumers to buy products or services that they like frequently, so that purchases with the same brand repeatedly (Kotler and Keller, 2016: 153). Consumer loyalty can be used to measure the development of sales and purchases. One way to increase consumer loyalty is to know the characteristics of consumer loyalty (Maulina, 2019).

Meanwhile, according to Suhaily and Darmoyo (2019), defining consumer loyalty is the willingness of consumers to maintain a relationship with the company. Maintaining consumer loyalty in order to remain loyal is not easy, therefore every company must maintain its quality. Customers who are increasingly loyal can increase profits and also profits of a company. So, companies must be smart in maintaining customer loyalty so that customers do not change their minds to go to other companies (Fardani, 2015). 


\section{Figure 1: Research Model}

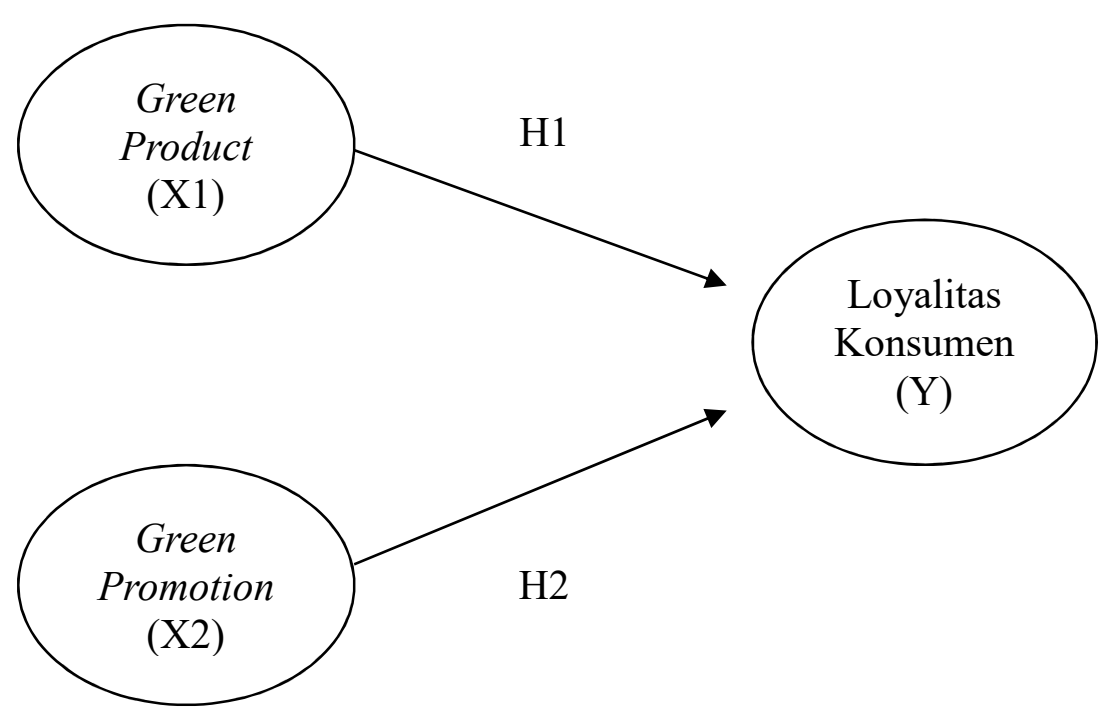

\section{METHODOLOGY}

This research uses quantitative research which a method of survey by distributing questionnaires online to respondents. The sample using a purposive sampling with the respondent criteria is respondents aged 17 to 35 years and know about green products and green promotion of Starbucks Coffee. The sample was obtained by using the Jacob Cohen formula with a total of 203 respondents.

\section{Data Analysis}

The questionnaire was measured using a five-point Likert scale. The data analysis using multiple linear regression, partial $t$, the coefficient of determination $\mathrm{R}^{2}$ and classical assumption.

\section{RESULTS AND DISCUSSION}

\section{RESULT}

\section{Characteristic of Respondent}

From the 203 respondents who have been obtained the results of the online questionnaire, the majority of respondents are women aged 17-25 years and work are students. With the acquisition of a percentage women is $78.3 \%$, age $17-25$ years 69.5 and students $50.2 \%$. 


\section{Analyzed Result}

This research has been tested the validity and reliability of using SPSS 25 . All the data has been declared valid by the acquisition of a calculated $r$ value bigger than $r$ table. The data is also said to be reliable with the acquisition of a Cronbach alpha $(\alpha)$ value bigger than 0,6 . The results of the normality test state that all data are normally distributed, with a significant value of 0,007 which is bigger than 0,05 . In the regression model it was stated that there was no multicollinearity with the result of VIF value was not more than 10,00, the purpose of using the multicollinearity test is to determine the existence of a strong correlation or relationship between independent variables. For the heteroscedasticity test, all the data stated that heteroscedasticity did not occur with significant values of green product is 0,688 and green promotion is 0,579 , the purpose of using heteroscedasticity test is to aims whether in the regression model there is a dissimilarity variant from the residual value to one observation to another observation. All variables have a linear model with linearity criteria lower than 0.05 .

Based on the partial $t$ test there is a results with significant value is less than 0,05 , which means that the variables are green product and green promotion have an influence relationship on the dependent variable consumer loyalty. Obtained the regression equation with the formula Consumer Loyalty $(\mathrm{Y})=3,983+0,291 \mathrm{X} 1+$ $0,181 \mathrm{X} 2+0,05$. It is mean that constant number of 3,983 shows the green product (X1) and green promotion (X2) if the value is 0 , then the consumer loyalty (Y) value is 3,983 . There is a green product coefficient $(\beta 1)$ of 0,291 with a positive value, meaning if the green product increases by 1 time or $1 \%$, then consumer loyalty will increase by 0,291 or $29,1 \%$. The value of green promotion coefficient $(\beta 2)$ is 0,181 with a positive value, that's means if green promotion increased by 1 time, then consumer loyalty will increase by 0,181 or $18,1 \%$.

The results of the determination coefficient test state that there is a $\mathrm{R}^{2}$ value of 0.222 , which means that the green product and green promotion variables have an effect on consumer loyalty by $22.2 \%$. While the rest is influenced by other factors or variables apart from this research.

\section{DISCUSSION}

Result of this study shows that green product and green promotion have a significant influenced to consumer loyalty. Green product can increase consumer loyalty by $29,1 \%$. Then green promotion can increase consumer loyalty by $18,1 \%$. The result of this study is supported by the research of Jabeen and Kavitha, 2020 that state green product and green promotion have an influence on consumer loyalty. They also state green product have the biggest influence on consumer loyalty.

The limitation in this research is focus on the object that is Starbucks Coffee and the respondent is taken by people that knows green product and green promotion at Starbucks Coffee. The variable of this research also focus on a few parts that is taken from the green marketing strategies. Further researchers can use other variables that are also related to green marketing, such as green place and green price to the future research. 


\section{CONCLUSION}

There is a significant influence between green product and green promotion on consumer loyalty at Starbucks Coffee. Green product have a biggest influence to increase consumer loyalty. This researchers have a suggest besides using a questionnaire method, it is advisable to use the interview or field survey by observing the surrounding conditions, so that as a result the information and data obtained can be more complete. The further researchers can use another object that have a green product and green promotion too. Also can use a few factors that can be effect on consumer loyalty.

\section{REFERENCES}

Fardani, N. E., \& Azis, E. (2015). Analisis Faktor-Faktor yang Mempengaruhi Loyalitas Pelanggan Mobile Broadband Services Telkomsel di Kota Bandung tahun 2014. eProceedings of Management, 2(2).

Febriani, S. (2019). Pengaruh Green Marketing Mix Terhadap Green Product Purchase Intention Pada Produk Innisfree Di Jakarta Dengan Consumer's Attitude Sebagai Variabel Mediasi. Jurnal Manajemen Bisnis dan Kewirausahaan, 3(1).

Hanifah, H. N., Nurul Hidayat, \& Rita Murtiani. (2019). Pengaruh Produk Ramah Lingkungan/Green Product Dan Harga Terhadap Keputusan Pembelian Produk Tupperware. Jurnal Riset Manajemen dan Bisnis Dewantara (JMD), 2(1), 37-44.

Iswanto, Rendy. (2019). "Green Design Starbucks". Diambil pada 19 September 2020 dari https://www.uc.ac.id/vcd/green-design-starbucks/.

Jabeen, S. S., \& Kavitha, M. (2020). Effect of Green Marketing Strategies on Customer Loyalty. Journal of Xi'an University of Architecture \& Technology. Volume XII, Issue IX.

Kotler, P. \& Keller, K.L. (2016). Marketing Management, 15th Edition. New Jersey: Pearson Pretice Hall, Inc.

Kusuma, E. I., Surya, D., \& Suhendra, I. (2017). Pengaruh Strategi Green Marketing dan Pengetahuan Lingkungan terhadap Keputusan Pembelian Melalui Minat Beli Sebagai Variabel Intervening (Studi pada member Tupperware di Kota Rangkasbitung). Jurnal Riset Bisnis dan Manajemen Tirtayasa, 1(1).

Maulina, Rishna. (2019). "Meningkatkan Loyalitas Konsumen dalam Persaingan 
Bisnis". Diambil pada 18 September 2020 dari https://www.jurnal.id/id/blog/meningkatkan-loyalitas-konsumen-dalampersaingan-bisnis/.

Palaguna, I. G. N. F., \& Ekawati, N. W. (2016). Green Promotion Memedasi Green Packaging terhadap Repurchase Intention (Studi pada Amdk Ades di Kota Denpasar). E-Jurnal Manajemen Universitas Udayana, 5(12).

Sari, I. G. A. W., \& Setiawan, P. Y. (2017). Pengaruh Green Marketing dan Packaging terhadap Brand Image dan Loyalitas Pelanggan pada Konsumen Starbucks Coffee. E-Jurnal Manajemen Universitas Udayana, 6(7).

Sari, K., \& Nurhayati, I. K. (2019). Pengaruh Strategi Komunikasi Pemasaran Starbucks Card terhadap Loyalitas Konsumen (Studi Pada Konsumen Berstatus Mahasiswa PT. Starbucks Coffee di Kota Bandung). Jurnal Ilmiah Komunikasi Makna, 7(2), 1-22.

Suhaily, L., \& Darmoyo, S. (2019). Effect of Green Product and Green Advertising to Satisfaction and Loyalty which mediated by Purchase Decision. International Journal of Contemporary Applied Researches. Vol. 6, No. 1.

Zuraya, Nidia. (2019). "Kemenperin: Industri Makanan dan Minuman Tumbuh 8 Persen". Diambil pada 18 September 2020 dari https://republika.co.id/berita/q0t79v383/kemenperin-industri-makanandan-minuman-tumbuh-8-persen. 